\title{
Roads "Drawn" to Modernity: Religion and Secularism in Contemporary Turkey
}

$\mathrm{E}_{\mathrm{b}}$ ditorial cartoons do not just mirror politics, The are also themselves a part of politics. They are more than single-panel graphical commentaries on daily policies, for they construct their own claims on truth. The cartoonist can use the polysemic nature of visual signs and present a distinct framing perspective. Editorial cartoonists with certain ideological stances can become an actor in "the struggle for cultural supremacy," in Tarrow's (1998) term. This struggle refers to efforts by the state, media, and social movements to influence the interpretative processes by which individuals negotiate the meaning of events. This paper analyzes the editorial cartoons in Turkish daily newspapers in terms of their competing framings of contemporary Turkey's secularistIslamist division. Secularism and Islamism refer here to political projects that seek to transform and reinstitute a sociopolitical order on the basis of some constitutive norms (Çınar 2005, 8-9).

by

Hakkı Tas,

Bilkent University

Meral Uğur,

University of Pennsylvania
Starting from the foundation of the Turkish Republic in 1923, Kemal Atatürk and his cadre unilaterally led the execution of a reform project aimed at modernizing Turkey. The secularization of the public realm - the

separation of religion and state affairsdeemed religiosity as an individual choice and as a private matter. On the other hand, religion remained under the indirect control of the state to avoid a rival source of legitimacy. Kemalist reforms sought to remove Turkish society from an Islamic framework and to create a new secular order (Eisenstadt 1984, 9). The national public sphere in Turkey was under the supervision of the secularist elite, whereas the religious groupings had been "marginalized by the Republic and pushed out of the centers of political power, social status and intellectual prestige, because of their opposition to republican reforms and/or their provincial-religious backgrounds" (Toprak 2005, 171).

It was not until the mid-1980s that Islamic public practices started gaining widespread visibility in politics, the economy, media, and art. The 1990s witnessed the rise of the Islamist Welfare Party and the development of several religious groups' economic and social wings, challenging the secular nationalist heg- emonic project. The massive rise of political Islam, which became possible only after the liberalizing reforms of Prime Minister Turgut Özal in the 1980s and the impact of globalization in early 1990s, deepened the secular versus religious entrenchment in Turkish society and led to serious political polarization. This paper traces the implications of this division in the editorial cartoons of three Turkish daily newspapers: the pro-state secularist Cumhuriyet, the mainstream secular Milliyet, and the Islamic wing's Zaman.

\section{Milliyet and Cumhuriyet: In Defense of Secularism}

As two representatives of the Kemalist secular wing, both Milliyet and Cumhuriyet ${ }^{1}$ see secularism as an indispensable element of the socio-political structure and favor the exclusion of religion from the public life and national identity. Cumhuriyet has a relatively stricter stance on secularism and intolerance, but both newspapers are similar in their appreciation of Kemalist modernism and act as the selfappointed guardians of the secular regime. These newspapers are highly occupied with maintaining a secular political/public realm, especially in terms of being alert against the "Other," which in this case are Islamists who try to impose their religious particularities to alter the public sphere and national image.

The editorial cartoons in these newspapers usually depict the Other with restrictive symbols confining him to his particular character in order to show that he is incapable of responding to the needs of society or of representing the whole. An example of the "stereotyped representation" (Akman 1997) of the Other with particular characteristics is a caricature drawn by Ercan Akyol (2003, May 18) in Milliyet, where he depicts the Justice and Development Party (Adalet ve Kalkinma Partisi-AKP), the party in office and known by its Islamist background, as a woman wearing a black carsaf, the veil covering the whole body except the eyes. Here, the party, drawn as a woman in black, completely veiled, has no place in the Kemalist secularist public sphere and political arena. Accordingly, the secular press denies the party the role of a capable actor who can embrace the whole community.

In the framing of the secularist-Islamist division, religious formations are not only 


\section{Figure 1}

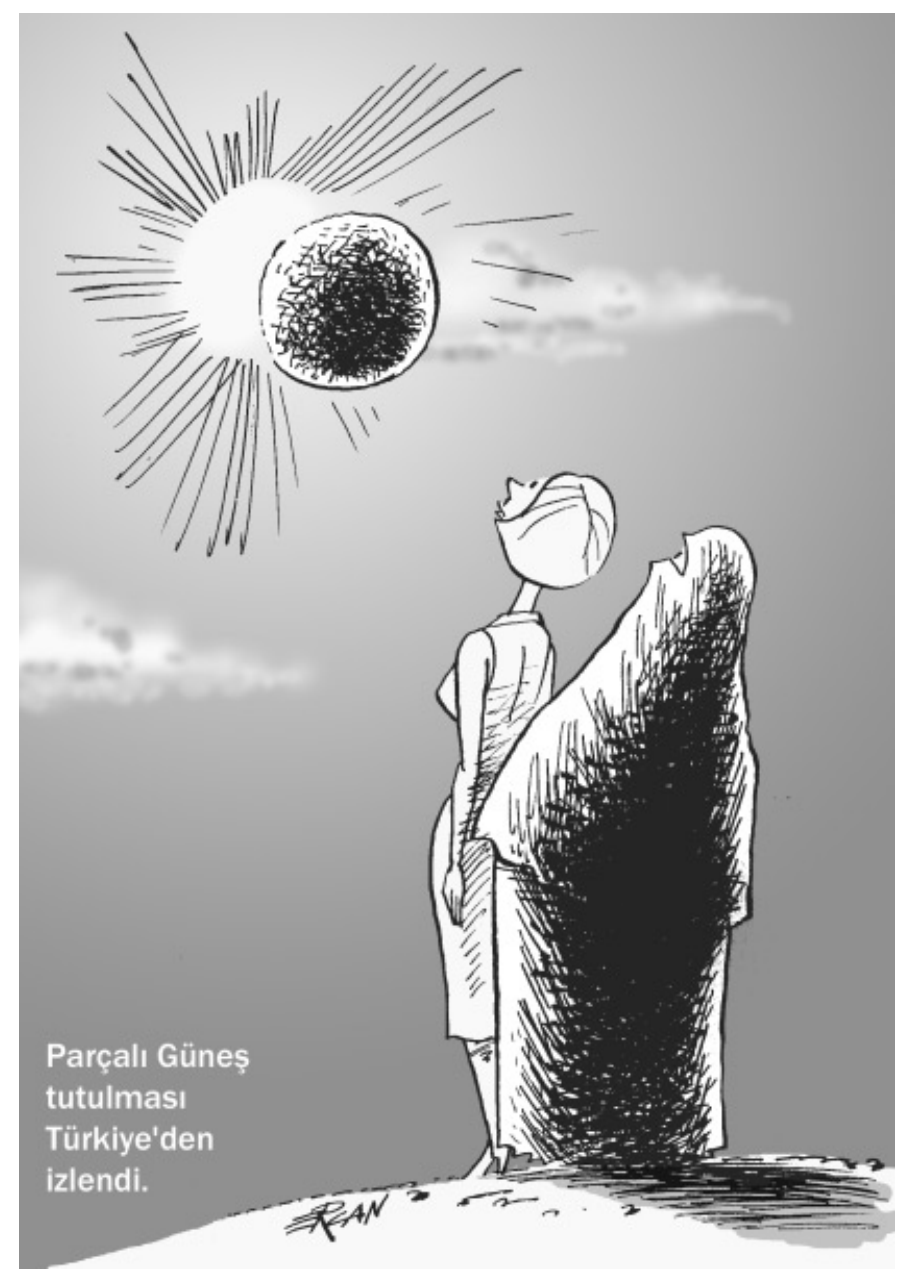

Used with permission.

re-articulated by their particularity and "strangeness," but also by their "deviant" nature from the norm (Goffman 1959). This process of stigmatization and denial of human potential reaches its peak in Turhan Selçuk's (2006, April 19) cartoon in Cumhuriyet, where he draws the Islamist Turkish woman as a pig on the way to the European Union. The provocative caricature, titled "Veiled Pig on the Way to EU," satirizes the veiled women who have applied to the European Court of Human Rights for the right to wear a veil in the Turkish public sphere.

The Other is not always depicted alone, but is sometimes juxtaposed with the "Self." This binary opposition of the secular and the Islamist reserves the abnormal and deviant connotations for the religious Other, whereas the secular Self is generally acceptable and legitimate. The cartoon drawn by Ercan Akyol (2003, May 31) in Milliyet substantiates this argument (Figure 1). He analogizes a recent partial solar eclipse viewable in Turkey to the country's "partial enlightenment," drawing its "dark" and "bright" sides together. In this cartoon, two women are watching the eclipse. One is wearing a black carsaf and the other is dressed in accordance with orthodox secularist expectations, signifying no religious particularity. Parallel to the eclipse, the latter stays on the side of the visible part of the sun, whereas the veiled woman stays on the shadowed side. The caption reads: "Partial solar eclipse has been watched in Turkey."

The darkness of the Other can also be used to emphasize the "threat" Islamism poses to the system. This brings us to another way of framing the secularist-Islamist division, where the other is viewed as completely dark, unable to peacefully adapt to or internalize the political system, and is therefore an alarming danger that invites extraordinary security measures (Buzan 1983). In another cartoon, Ercan Akyol (2003, March 28) depicts a woman with a carsaf menacingly holding a gun. In another example, Turhan Selçuk (2001, November 3) draws a large group of women dressed in carsafs walking together in a threatening way, connoting intolerant backwardness. Under this cartoon, there is a reference to a line from the 10th Year March of the Republic (Onuncu Yıl Marssı), which is widely sung among secular circles: "We came out victorious from every war in 10 years." It gives the message that the secular principles and the enlightenment project for which the Turkish state struggled after the establishment of the Republic are now under threat.

\section{Zaman: Quiet Subversion}

Cartooning only developed recently among the Islamist circles in Turkey, probably because of the strict religious restrictions on drawing (Arnold 2002) and the late development of Islamic capital to sponsor powerful media outlets. ${ }^{2}$ Only after the winds of liberalization and globalization swept Turkey over the last two decades did it become possible for the Islamists to enter into or create their own "public sphere" (Göle 1996).

In 2002, the Zaman ${ }^{3}$ daily newspaper, which belongs to a moderate religious group led by Fethullah Gülen, attempted a revolutionary innovation by giving the largest print space for editorial cartoons in Turkey. Zaman's editorial team presented the cartoons as visual columns and placed them on the opinion page. Dağistan Çetinkaya's drawings were not typical comedic reliefs, but highly artistic and surrealist cartoons, the sophistication of which led readers to complain (Kutay 2006, April 8). Unlike other editorial cartoons, Çetinkaya's do not feature caricaturized figures of politicians and they often lack humor; they are more bent on provoking thought and discussion.

Çetinkaya's cartoons can be understood on several different levels. First of all, in Turkey, cartooning and art, in general, have been considered monopolized by the secular and leftist elite. Çetinkaya's artistic cartoons subvert this monopoly. Although he admits that his cartoons are not appropriate for daily newspapers, Zaman's decision to publish them can be understood as an attempt to challenge the common Turkish stereotype that the religious cannot produce sophisticated artistic and intellectual works. Second, humiliating a person-even through caricature - is considered an unacceptable practice in Islamic terms; this considerations might have led to Çetinkaya's more vague style of drawing. Instead of funny depictions of politicians, for example, Çetinkaya uses elusive symbols. In some cases, he manipulates trees, clouds, or a lowly animal like a snake to denote the secular elite, which he sees as oppressive and alien to the Muslim community (Çetinkaya 2003, December 8). His illustration of a tree bowed by an approaching cloud, yet still growing is an example of how the caricaturist can indirectly express the power relationship between the "oppressive" secular elite and the "inferior" religious groups-as defined by the seculars (Çetinkaya 2002, April 29). Accordingly, the religious segment is depicted as a higher entity that cannot be prevented from growing. It implies that the cloud in the sky seems superior to the tree on the earth, but time will prove the opposite (Figure 2).

In fact, Çetinkaya's cartoons are kaleidoscopic, containing multiple meanings according to the perspective of the reader. This ambivalence leads us to their third layer. Zaman's publishers are aware of their inferior-defined status within the sociopolitical arena, and of the depiction of Islamism as constituting a potential threat to it. Cognizant of the perceived threat 


\section{Figure 2}

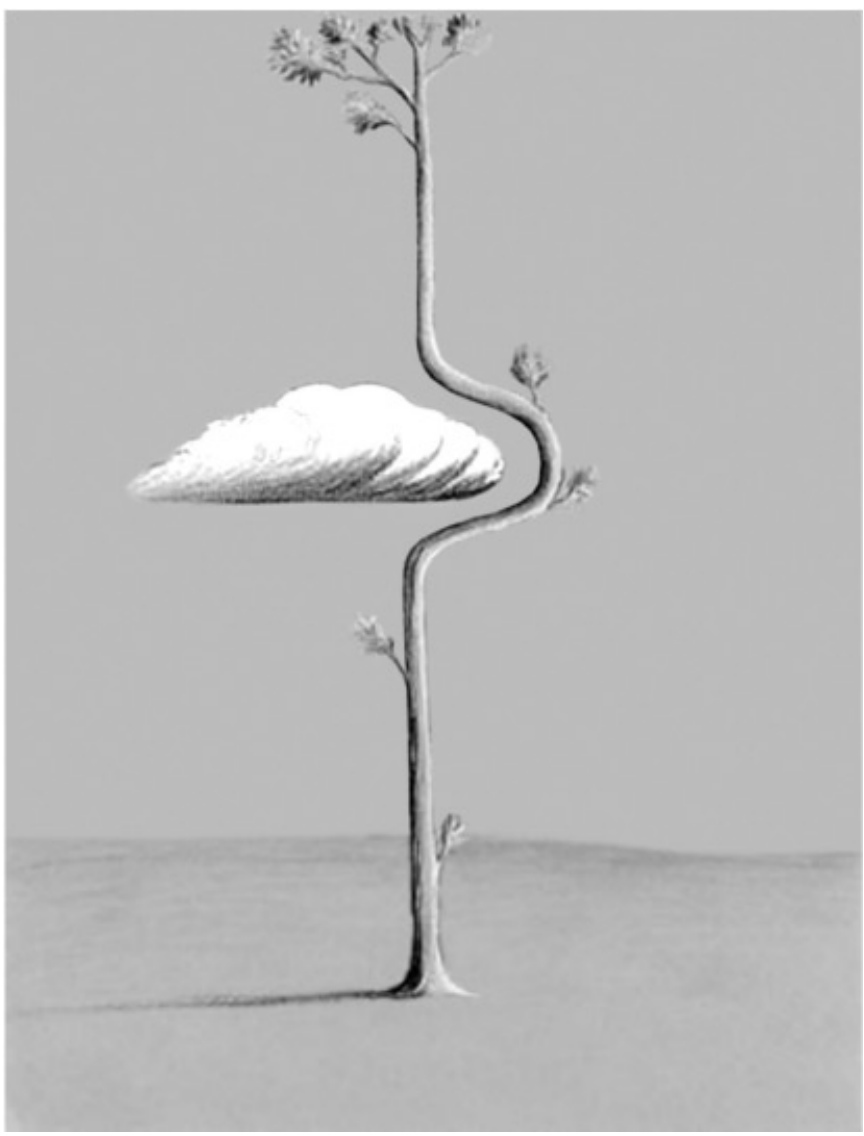

Used with permission.

Islamism poses in the public eye, Çetinkaya never blatantly attacks Turkish society; he practices his subversion indirectly through symbolism. Ambivalent drawing therefore becomes an important facet of the struggle for cultural supremacy. Unlike the editorial cartoons found in secular Milliyet and Cumhuriyet, Zaman neither uses binary oppositions nor openly caricaturizes the Other, since such duality is not supported by a legitimizing principle such as Kemalism. In a more recent cartoon, Çetinkaya (2004, January 6) illustrates the resentment of some religious groups as a (typically traditional and religious-looking) man who is put into a huge labyrinth without any exit, who then destroys the walls to get out (Figure 3). There is no concrete Other in the drawing, but only its implication as someone who constructs this labyrinth — the system — and determines the way for people, although they do not end up with an exit, namely freedom. The cartoon casts strong criticism upon the secular hegemonic system, but in a very indirect and symbolic way.

Zaman readers frequently complained about the high level of sophistication of these editorial cartoons, and the editorial team felt compelled to replace them with a new "light" cartoon series two years later, entitled "The King and the Buffoon" (Kral ve Soytari) and also drawn by Dağistan Çetinkaya. Funny figures and speech balloons replaced the surrealist drawings in the former editorial page, but the latter continue to appear under a separate link with its original name "DrawingComments" (Cizgi-Yorum) on the newspaper's web site, whereas the new caricature series appears under the "entertainment" (mizah) link. Although Çetinkaya, in this series, focuses more on current political issues, he continues the subtle understating that characterized the messages of his previous cartoon,

\section{Figure 3}

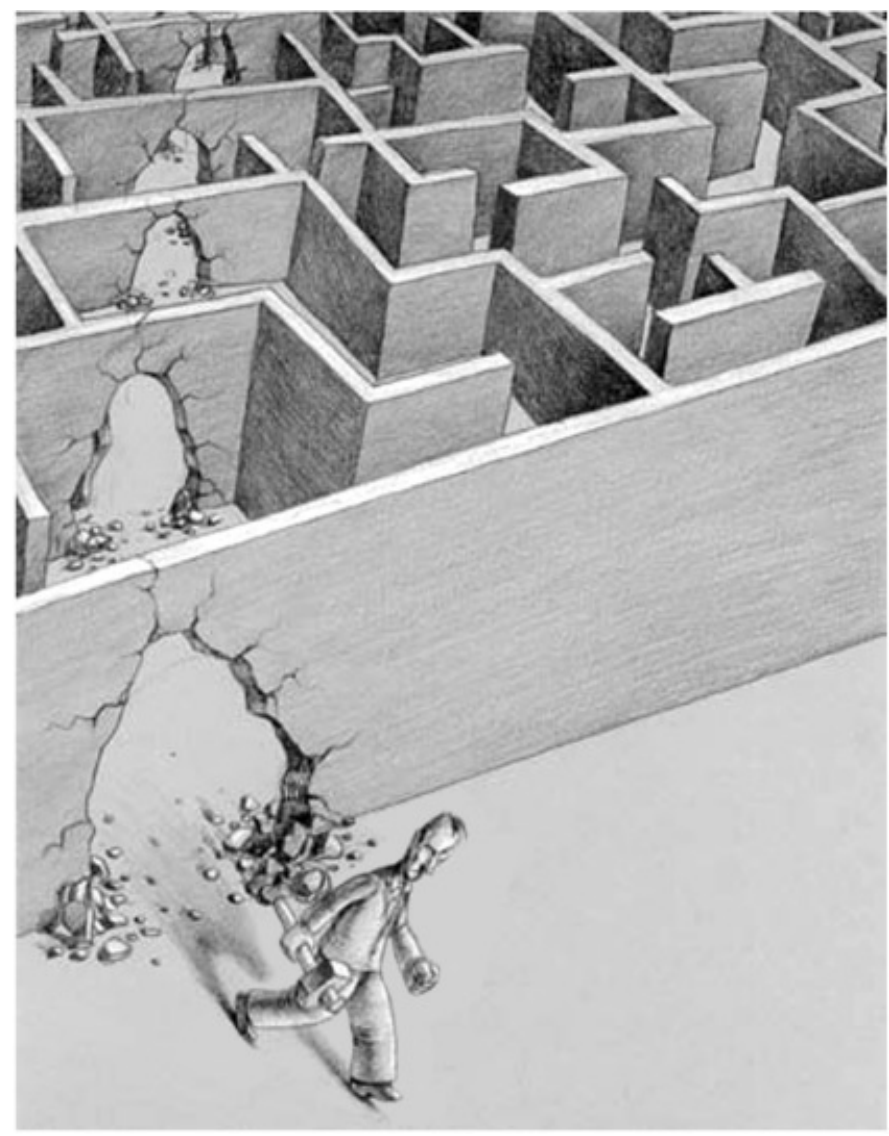

Used with permission.

a marked departure from the overtness of message displayed in the secular media. Instead of directly depicting current-day politicians, he uses the king, the buffoon, and, occasionally, additional figures from the king's court, as proxies. In this configuration, the king represents the secularist state, and the buffoon is the citizen. The use of the image of a king instead of that of a sultan is a conscious choice to illustrate how the state elite are alienated from Turkish society and culture. The king is depicted as incompetent, ignorant, and egoistic. On the other hand, the unlucky and oppressed buffoon represents both the Turkish citizen and, more specifically, Turkey's "oppressed" Muslims. The cartoon simultaneously gives the message that the local/religious citizen is the "genuine" Turkish citizen. The binary oppositions, which are apparent in Milliyet and Cumhuriyet, but absent in Zaman's former series, constantly appear in these cartoons in the king/buffoon allegory. Zaman still does not feel that it can directly challenge the secular elite, but it clearly does so indirectly. ${ }^{4}$

\section{Conclusion}

The struggle for cultural supremacy in Turkish editorial cartoons can best be understood by viewing the endeavors as modernist projects in which both sides enter into a struggle to apply their projects to the state and society, as well as to make their identities acceptable for a broader community. They do this by reproducing the political context. They can present competing frames of the same contexts; however, the tools of framing depend on the relative power position of one's political stance. 


\section{Notes}

1. Milliyet is one of the most widely read newspapers in Turkey. Cumhuriyet, though not as widely read, still has a large number of "loyal" readers.

2. The recent economic development of religious segments in Turkey has created much controversy around the "Islamist Calvinists" debate. For an extensive review of the Islamist Calvinism debate in Turkish media, see M. Gürbüz, "Worldly Asceticism and Secularization: A Critique of Weberian (Mis)Readings of the Gülen Movement," in Challenges and Responses of Contemporary Islamic Thought: The Contributions of M. Fethullah Gulen, ed. Ibrahim Abu-Rabi (Albany: SUNY Press).

\section{References}

Akman, A. 1997. "From Cultural Schizophrenia to Modernist Binarism: Cartoons and Identities in Turkey, 1930-1975." Princeton Papers: Interdisciplinary Journal of Middle Eastern Studies 6 (2): 83-133.

Akyol, E. 2003. Cartoon. March 28. Milliyet. 2003. Cartoon. May 18. Milliyet. 2003. Cartoon. May 31. Milliyet.

Arnold, T. W. 2002. Painting in Islam: A Study of the Place of Pictorial Art in Muslim Culture. New Jersey: Gorgias Press LLC.

Buzan, B. 1983. People, States and Fear: An Agenda for International Security Studies in the Post-Cold War Era. Harvester Wheatsheaf, NY: Lynne Reinner.

Çetinkaya, D. 2002. Cartoon. April 29. Çizgi-Yorum, Zaman

- 2003. Cartoon. December 8. Çizgi-Yorum, Zaman 2004. Cartoon. January 6. Çizgi-Yorum, Zaman. 2005. Cartoon. December 31. Çizgi-Yorum, Zaman.

Çınar, A. 2005. Modernity, Islam, and Secularism in Turkey: Bodies, Places, and Time. Minneapolis: University of Minnesota Press.
3. Zaman has one of the largest circulations in Turkey. It shows a moderate conservative stance. Although there are radical Islamist newspapers in Turkey, they are remarkably isolated from the current sociopolitical arena.

4. The only exception to this style in this series appeared on December 31, 2005, New Year's Eve, when Çetinkaya drew some dogs entertaining themselves. The caricature received harsh criticism and was pulled from the newspaper's web site by the administration.

Eisenstadt, S. N. 1984. "The Kemalist Regime in Comparative Perspective: Some Cooperative and Analytical Remarks." In Atatürk and the Modernization of Turkey, ed. J. M. Landau. Boulder, CO: Westview Press.

Goffman, E. 1959. The Presentation of Self in Everyday Life. New York: Doubleday Anchor.

Göle, N. 1996. Forbidden Modern: Civilization and Veiling. Ann Arbor: University of Michigan Press.

Kutay, F. 2006. "Çizgileri Bizi Aşıyor (His Lines Overstep Us)”; "Okur Hattı (The Reader Line)." Zaman, April 8.

Toprak, B. 2005. "Islam and Democracy in Turkey." Turkish Studies 6 (2): $167-86$.

Selçuk, T. 2001. Cartoon. November 3. Cumhuriyet. 2006. Cartoon. April 19. Cumhuriyet.

Tarrow, S. 1998. Power in Movement: Social Movements and Contentious Politics, 2nd ed. New York: Cambridge University Press. 